\title{
Dos efeitos de real a uma política do ócio em Abbas Kiarostami
}

\section{Demétrio Rocha Pereira}

Doutorando; Universidade Federal do Rio Grande do Sul, Porto Alegre, RS, Brasil

demetrio.pereira@gmail.com

\section{Felipe Diniz}

Doutor; Universidade Ritter dos Reis; Porto Alegre, RS, Brasil

fildiniz@hotmail.com

\section{Lennon Macedo}

Mestrando; Universidade Federal do Rio Grande do Sul; Porto Alegre, RS, Brasil lennon-macedo@hotmail.com

\section{Resumo}

Abbas Kiarostami aplica em seus filmes e escritos certa técnica de produção de real a partir da observação de pequenos detalhes em contínuo movimento. Este artigo investiga como o cineasta elabora o ócio enquanto dispositivo para instalar no espectador um efeito de real. Esse mesmo procedimento de estudo do supérfluo e do ínfimo se codifica diferentemente quando subordinado às causalidades narrativas, resultando numa semiótica da ingenuidade. Com o suporte dos estudos de André Bazin, Christian Metz, Roland Barthes e Jacques Rancière, traçamos um caminho que apresenta personagens humanos e não humanos como vetores obstinados de uma política do ócio.

\section{Palavras-chave}

Abbas Kiarostami. Efeito de real. Ingenuidade. Ócio. Semiótica do cinema.

\section{Realização ingênua: fabular outros fins}

Recorre no cinema de Abbas Kiarostami que, para satisfazer um objetivo único, por simples que seja, o herói precise trair um lugar social designado: sendo criança, desviar-se das imposições familiares para devolver o caderno do colega; sendo analfabeto e sem-teto, 
provar o seu valor para uma donzela protegida pela família; sendo pobre, virar cineasta. Personagens que descobrem o seu papel no momento mesmo em que recusam um papel habitual. 0 cinema de Kiarostami começa quando o marasmo cotidiano sofre um desvio casual, preferencialmente bobo, para que as vozes disciplinadoras sejam apanhadas em fragilidade, erguendo tribunal contra a mais mínima abertura para a imaginação.

De fato, quem faz as leis sabe muito bem que, mal tenha legislado, alguém conseguirá evitá-las por meio dos artifícios mais variados. Nenhuma lei é tão séria que mereça ser respeitada. Além disso, creio que as sociedades com uma cultura e um passado muito antigos, como o Irã, dificilmente pactuam com a lei. (KIAROSTAMI, 2004, p. 218).

Ora, não será fácil restituir o caderno ao amigo (em atenção à lei disciplinar) se a condição da criança é a de um meio de comando (como manda a tradição familiar). Em Onde fica a casa do meu amigo? (1987), Ahmad só tem deveres, os mais diversos, inclusive contraditórios entre si. Mandam-no carregar roupas, embalar o bebê, estudar, comprar pão, trazer cigarros... Mas o que acontece quando Ahmad elege um dever maior e passa a construir por si os imperativos do seu movimento? Um amigo em apuros há de configurar um problema maior do que a compra do pão...

De início, o gesto de autonomia se confunde com uma extrema sujeição: Ahmad satisfaz um imperativo escolar, garantindo o bom cumprimento das ordens do professor, trabalhando contra o acaso (a perda do caderno) e pelo restabelecimento da rotina. Mas, falhando em encontrar a casa de seu amigo, Ahmad pode consumar uma descoberta. No que preenche ele mesmo o caderno de Nematzadeh, Ahmad dissolve a onipotência da lei disciplinar, restando ao professor uma eficácia não mais que teatral: a autoridade não distingue entre quem obedece e quem sabe fingir que obedece. Se, por um lado, a disciplina impera sobre os movimentos do aluno, por outro, ela não pede mais do que o cumprimento de um papel, no momento preciso em que o papel é chamado a palco. Falsificar o dever constitui, assim, o gesto transformador que dá sentido à aventura de Ahmad. Mediante essa transgressão vitoriosa, garantidora de um final feliz, Ahmad deixa a condição de objeto de poder e se afirma como sujeito experimentador. A sua descoberta não é um enjambre caligráfico, a mentira, a revolução ou sequer a desobediência, mas fissuras inerentes à lei, 
por onde se pode praticar uma ética própria. Ahmad inventa-se, assim, um outro modo de convivência com o regime disciplinar.

Não parece que outra criança teria feito o mesmo. Kiarostami se interessa pelos tipos sociais, mas na medida em que o sujeito saiba falsear a sua generalidade. Ahmad reivindica protagonismo não só por sensibilidade e camaradagem, mas pela prontidão com que afirma esses caracteres teimosamente. 0 herói de Kiarostami é um insistente, mesmo que esse insistir ache como fundamento paradoxal o abandono à vida (possibilidade mesma de insistir): em nenhum outro filme tanto quanto em Gosto de Cereja (1997) o diretor deixará tão evidente o tema do abandono de si, que atravessa todo o seu trabalho.

Levou longo tempo até que Kiarostami atinasse em outros finais que não os felizes (cf. o recente Cópia fiel, de 2010, que termina sem acalmar nenhum dos fantasmas amargos com que, pouco em pouco, ensombrece uma paisagem de romance fácil), pois o autoabandono, enquanto processo, vai culminar em uma bem-sucedida reinvenção de si, tema especialmente pesquisado em Close-up (1990).

Para uma análise eloquente sobre a relação entre arte e realidade, sobre o caráter intrinsecamente artístico do real e profundamente real da arte, não precisamos procurar além da fala de Sabzian, que responde em tribunal à acusação de ter se passado por outra pessoa. Homem humilde, preocupado em ter o que comer e, com sorte, voltar para casa com agrados para a filha, Sabzian é também um cineasta. Ou assim ele alega? Basta reconhecer em Sabzian um apaixonado por cinema, alguém que "acredita" ser um cineasta? Seria preciso ir até o fim e afirmar que Sabzian efetivamente dirigiu um espetáculo, tomando como atores os membros de uma família de classe média que, agora convencida de ter sido engambelada, se sente atingida em sua respeitabilidade. Só um juiz para pensar que Sabzian mente para enganar os outros ou mesmo por autoengano: o que está em questão é menos alguma distância inapreensível do Real do que o efetivo caráter realizador de uma máquina cinematográfica de fingimento e brincadeira. Assim como Ahmad, Sabzian consegue dar consistência a um novo imperativo de existência, e é mesmo disso que o acusam: ter atentado contra a ordem estável da realidade. Criminoso foi, precisamente, ter se tornado autônomo o bastante para a produção eficaz da realidade, ou seja, devir realizador.

0 diretor que assina esse intrincado brinquedo narrativo, o nome responsável por destramar os limites entre documentário e ficção, não faz outra coisa senão repetir a 
ousadia fabulatória do seu protagonista. Hesitamos, como a família ludibriada, entre decretos ora de espontaneidade, ora de fingimento. 0 encanto desse cinema é que, ao iludir, ele relata; ao mentir, ele diz a verdade.

E se o real for mesmo o indecidível, e se ele traz consigo a forma da promessa? Se Sabzian tem tanta força de iludir audiências, é porque firmou uma promessa consigo mesmo, calcada em um dever maior, pelo qual se torna urgente que um indivíduo não permaneça idêntico a si mesmo, fadado a desempenhar um papel decidido por outros. Quem poderá dizer que Sabzian é um pobre coitado e não um grande cineasta, um artista de especial inteligência e sensibilidade? Escutamos uma voz em posse de sua arte, a ponto de reconhecer os seus intercessores e fazer a teoria de si: "sou o ator mais capaz de interpretar a mim mesmo, pois só eu conheço os meus problemas e as minhas dores". A identidade não aparece aqui para reafirmar uma função social, senão todo o inverso: campo problemático para a realização de um ser-outro. É porque conheço muito o lugar do não artista, é porque vivo intensamente a impossibilidade de tornar-me narrador de minha própria história, que o cinema precisa de mim e que um devir-artista me atravessa.

Não é difícil supor que a recepção amplamente favorável ao cinema de Kiarostami esteja ligada a um reencantamento de mundo candidato a remediar todo um conjunto de incertezas que, com o avanço da industrialização e a metropolização da vida, se instalou no mundo ocidental. Seria necessário examinar os diversos agenciamentos discursivos que participam da emergência desse cinema que vem anunciar a vitória da simplicidade, a beleza na lentidão, a promessa do real... Kiarostami gosta de personagens que não apenas são desvalidos como também, aos olhos de uma audiência urbana, resguardam alguma pureza perdida, residualmente acessível aos tolos e ingênuos.

Lembramo-nos de Bartleby, com quem Melville (1853/2014) descobriu uma recusa de agir que dá testemunho de uma liberdade irrestrita, sem objeto porque sem preferência. 0 ócio disfuncional de uma senha repetitiva ("eu preferiria não") assombra a verticalidade da empresa. Talvez seja impreciso acusar Bartleby de passivo, já que ele inventa um mantra autossuficiente que não somente o imuniza contra determinações vindas de fora, como também contagia, centrifugamente, os outros. Bartleby permanece imóvel e inescrutável enquanto o seu patrão, desorganizado, se atira em errância. Bartleby faz de si, assim, um 
perigoso limite desindividuante, ilógico, que Nova York enfim decide encarcerar até que, enjaulado, morra de fome.

Como alguns dos personagens de Kiarostami, Bartleby ameaça desrealizar um mundo já codificado, e nos parece significativo que estejamos sempre tratando de figuras simples, antidisciplinares por ingenuidade.

Claro que não convém igualar as narrativas: em Kiarostami, é importante que o herói responda a uma situação concreta e localizada. Sabzian não é um teimoso da preferência qualquer; a questão é que ele prefere o que não lhe é permitido, tal como Hossein, de Através das Oliveiras (1994), prefere obstinadamente, entre as moças, imaginar-se com aquela que teima em negligenciá-lo por completo. 0 que permanece, de nosso pequeno détour literário, é a impressão de que, sufocados em sua capacidade de decidir o mundo, esses personagens passam a insistir um refrão próprio - e o repetem quantas vezes for necessário até que, ao menos para os filmes de Kiarostami, atinjamos uma síntese alegre das contradições. 0 que acontece depois que Ahmad salva seu amigo de ser expulso da escola? Reunidos em casamento, como vivem Hossein e Tahereh? Perdoado pelo tribunal da identidade e pelo célebre diretor que ousou personificar, Sabzian achará os meios para se tornar artista? A poesia de Kiarostami não desenvolve essas questões. É possível que toda essa ingenuidade criadora se apague tão rapidamente quanto faiscou, retornando cada personagem ao tédio estrutural do qual haviam partido. Seria a brevidade da invenção um aspecto próprio da estética de Kiarostami? Uma trilha em zigue-zague oferece mudanças bruscas de direção, mas continua sendo uma rota já sulcada pelo hábito, já balizadora de um percurso, já realizada. Kiarostami afirma a beleza desse movimento obstinado, tanto mais comovente quanto mais estreito for o caminho. Como deixar de perceber, nesses filmes, um afeto quase indulgente por quem se ilude, por quem erra, por quem se confunde, por quem se perde e fantasia, contra a ordem do mundo, outra coisa para si?

Pergunta esta que implica as experimentações enunciativas de Kiarostami. O que faz a câmera desse diretor? Em relação ao narrado, de onde ela narra? 0 que a interessa? Ela também se transforma? Ela se coloca em questão? Ela participa da ingenuidade daquilo que ela filma? Os filmes mais recentes de Kiarostami parecem aderir cada vez menos à poética da parábola, evitando devolver o conflito à resolução ou a um estado conciliatório (ao lado dos filmes que já mencionamos, são nisso exemplares também o primeiro filme do diretor, $O$ 
pão e o beco, de 1970, e Duas soluções para um problema, de 1975, em que a "moral da história" vem subordinar por completo a imagem). Kiarostami diz que a simplicidade resulta de um longo e difícil trabalho, e não é sem o seu próprio percurso de transformação que o diretor descobre aquilo em que Ishaghpour reconhece uma "recusa da história":

A recusa da história, o "incidente simples", o retorno ao natural imediato liberam o mundo de toda significação, liberam-no sobretudo da imagem e do imaginário. Despojada de imaginário, sem vontade de significar, de exprimir, a imagem (re)encontra sua função de reproduzir o que está diante da câmara: "a vida e nada mais". Como a vida não simboliza nem representa nada e supostamente está presente em si mesma, basta que a imagem seja a revelação dessa presença, apresentando-se ela mesma. (ISHAGHPOUR, 2004, p. 123).

A câmera de Kiarostami vai se imobilizando, o enquadramento retorna à sua fixidez cinematográfica de origem, a variação agora depende de movimentos sutis (notadamente em Dez, de 2002; Cinco, de 2003; Shirin, de 2008 e Seagull eggs, de 2014). Parece que a trajetória de Kiarostami desenha, ela própria, um percurso transformador que parte da romantização da pessoa simples para a simplificação do observar. No desejo de um "natural imediato", sentimos Kiarostami ainda romantizar um Real livre de signos. Seria preciso lembrar que Kiarostami é um produtor de imagens técnicas, reconhecer em suas imagens uma realidade propriamente imagética, sem dívida nenhuma com algum mundo exterior ou superior. Ao emudecer o piano e abrir as portas da sala de concerto para os sons que vêm da rua, John Cage queria menos denunciar a mentira da música simbólica do que romper a sua bolha de idealidade. A abertura é da própria música, na música, pela música. 0 que vem invadir o teatro não é o mundo real liberado do signo, mas todo um outro concerto de signos, em sua bobeira cotidiana, compondo música, enquanto problema de música, tal como Sabzian invadiu o filme para se inventar como problema cinematográfico.

Enquanto o herói fabula ingenuamente desviar-se da realidade estabelecida, a câmera busca pescar um "natural imediato" que libere a imagem de "toda significação". Há uma crítica empenhada em mostrar a presença da herança neorrealista no trabalho de Kiarostami, à qual se opõe uma crítica que remove o cineasta iraniano das fileiras de qualquer realismo - e, em qualquer caso, tem-se esse cinema mobilizando o Real enquanto 
problema. 0 que tem a ingenuidade que a explique como traço do Real, senão essa sua desatenta aptidão para o desvio casual?

Os desvios que o motorista deverá seguir o levarão a pedir informações sobre o caminho inúmeras vezes: esse é outro traço característico da trajetória. 0 motorista desconhece o caminho e precisa dos outros para se orientar, o que lhe permite dialogar com pessoas com quem não se relacionaria, se soubesse o caminho. (BERNARDET, 2004, p. 47).

É por isso que Kiarostami poderá prescindir de um agente humano como protagonista, já que a ingenuidade do desvio, pertencendo ao Real, pode ser visualizada onde quer que haja um fluxo traçando trajetória por entre obstáculos:

A poesia persa define esse movimento como o curso de um riacho num prado. A água nunca segue linha reta. A essência de seu movimento é o obstáculo. 0 que obstrui a água a obriga a se movimentar. Essas curvas e meandros, que fazem a beleza dos riachos, provêm de seu encontro com obstáculos. (BERNARDET, 2004, p. 86).

Uma lata rola ladeira abaixo, saltitante em cada sulco de asfalto e barrada pelo degrau da calçada (Close-up, 1990). Revezando golpes de maré, o oceano engole, um a um, ovinhos de gaivota que sambavam em uma poça d'água entre as rochas da encosta (Seagull Eggs, 2014). Na areia, as ondas conduzem a marcha errática de um tronco de árvore (Cinco, 2003). Eis o "natural imediato" a que alude Ishaghpour (2004): movimento à toa, ditado por seus obstáculos; fluxo ocioso sem finalidade, definido pelo acaso que o desvia.

0 desvio teimoso do indivíduo socialmente desvalido vai assim dando lugar à atratividade hipnótica de um fluxo impessoal, o diretor aí buscando "[...] captar momentos e fazer filmes que não são construídos, mas sim 'pescados': as coisas existem e, por meio do digital, são pescadas." (KIAROSTAMI, 2004, p. 323). 0 mundo já está lá, existindo - trata-se de pescá-lo visualmente, numa paradoxal atitude antipredatória, pela qual a pesca busca não interferir no destino do pescado: "[...] esse tipo de trabalho pode se aproximar, de certo modo, da poesia, da pintura, e libertar-se da narração e da direção. Não a ponto de o autor desaparecer, mas no sentido de que não haverá uma encenação. Você continua sendo autor, mas se elimina como deus da cena." (KIAROSTAMI, 2004, p. 323). 
A morte de deus equivale, neste cinema, à morte da encenação enquanto prédeterminação do curso dos eventos. Já não cabe ao diretor incidir sobre os fluxos do real; o desvio não mais resulta de uma fabulação obstinada; basta agora que a câmera seja testemunha do movimento e de sua inevitável imprevisibilidade. Kiarostami se libera, fundamentalmente, da finalidade do movimento fabulatório, característica de seus filmes "de personagem", que culminam no cumprimento de um objetivo. Dir-se-ia que a finalidade era o que se interpunha entre Kiarostami e a ociosidade impessoal, amoral, requisitada por um projeto poético desejoso de pescar a beleza do real.

\section{0 real como questão cinematográfica: Bazin, Metz, Barthes}

O debate em torno do real toca num ponto determinante da pesquisa semiótica do cinema. Reconhecer que tanto o filme quanto a realidade não são mais do que signos em constante transformação e tradução levanta uma série de questões acerca do estatuto desses signos, de seu comportamento, da ocorrência de tradução entre o mundo das imagens e as imagens do mundo. A operação do cineasta, mesmo quando objetiva livrar-se de si, é coisa inventiva e mediada, é instância tradutória de ingenuidades alheias, como as das crianças, como as de Sabzian, mas também é tradução ociosa dos movimentos do mundo; sob o signo do ócio, de sobras de som e de imagem que pouco estimam compactuar com a Lei e a Regra, Kiarostami codificará o cotidiano globalizado dos pequenos detalhes, dos objetos insubordinados.

É a crítica de cinema europeia dos anos 1980 e 1990, às voltas com o pósmodernismo e com as teses acerca do fim das grandes narrativas, que festejará uma espécie de retorno ao real imediato nos longos planos do cineasta iraniano (ISHAGHPOUR, 2004). Típico do saber ocidental: tratar a poesia alheia como mera observação da natureza. Necessário se faz, portanto, descolar as imagens de Kiarostami do estigma da imediação, da ideia de uma captura não significante da natureza como se fosse o cineasta uma espécie de bom selvagem cinematográfico.

No tocante à relação entre cinema e realismo, inarredável que ingressemos nas teses de André Bazin e Christian Metz. É aquele primeiro quem fundamenta a defesa da vocação 
realista do cinema, perspectiva segundo a qual "[...] a imagem não vale pelo que acrescenta, mas pelo que revela da realidade." (BAZIN, 1991, p. 77). Move essa crença uma dada organização dos componentes da linguagem cinematográfica, podendo-se reconhecer a concepção realista do cinema como um sistema de expressão. Bazin, como se sabe, não é unanimidade no círculo da teoria e da crítica cinematográfica, e Christian Metz lhe imputará um realismo essencialista que ameaça recair em um "sentido natural" a ser buscado (ou pescado...) nas coisas. Bazin soaria desconfortavelmente determinista e metafísico, ao que Metz rebate afirmando que, no mundo "real", nenhum evento tem sentido a priori - o sentido seria expresso em nome de uma ambiguidade que, imanente ao mundo, o cinema seria capaz de enunciar de forma objetiva.

Problematizando essa relação entre cinema e realidade, Metz entende haver uma impressão de realidade produzida pelo cinema e desencadeada no imaginário do espectador através de um processo perceptivo e afetivo. Tal impressão de realidade estaria ligada a um espectro de indicialidade decorrente dos próprios materiais que constituem cada diferente espetáculo, como o teatro, a fotografia e o próprio cinema. 0 teatro, por exemplo, seria excessivamente real, participando da vida de maneira mais descarada, visível. Em tal estado de nudez, o teatro não seria apto a reproduzir a vida, já que se situa muito próximo dela, tendo, portanto, a sua "[...] credibilidade da realidade diegética enfraquecida [...]" (METZ, 2006, p. 26). 0 autor desenvolve a noção de realidade, desse modo, enquanto investida pelo universo da ficção (diegese); esta, no caso do teatro, se torna insuficiente, despida pela presença real do ator e pela integralidade do cenário, acobertada pelo espaço concreto do palco.

O cinema, por sua vez, teria a paradoxal vantagem de ser confrontado como um espetáculo irreal. Diferentemente do teatro, a impressão de realidade no cinema é imposta pela diegese. Enquanto o teatro instala a sua produção de realidade no seio de um espaçotempo também ocupado pela realidade da audiência, com a qual concorre mais diretamente, os materiais fílmicos permitiriam à diegese adquirir alguma realidade, principalmente a partir da realidade do próprio movimento. Assim, o cinema se preenche de índices de realidade sem que as imagens deixem de ser percebidas como imagens. Os mecanismos cinematográficos não expressam apenas a reprodução do movimento, e assim o meio 
cumpre um papel de "[...] injetar na irrealidade da imagem a realidade do movimento." (METZ, 2006, p. 28).

Em pesquisas posteriores, Christian Metz (1980) revê a ideia de impressão de realidade como um fundamento perceptivo inerente à sétima arte. Deixando para trás o viés fenomenológico para dedicar-se ao estudo semiológico do cinema, o autor insere a discussão da realidade no universo do ícone e da analogia; ou seja, o real deixa de ser questão de percepção e passa a configurar-se como um problema de código.

A esta primeira categoria de códigos, a que se liga a iconicidade visual, pertencem ainda (ou melhor: pertencem primeiramente) diferentes sistemas de uma grande importância antropológica, que nomearemos os "códigos da analogia" os que são responsáveis pela própria analogia [sic], que operam com vistas à "semelhança", que fazem com que o objeto semelhante seja percebido como tal; a analogia não é o contrário da codificação, ela própria é codificada, embora seus códigos tenham a característica própria de serem sentidos como naturais pelo usuário social; trata-se de todo um conjunto de montagens psicofisiológicas, integradas à própria atividade perceptual, e cujas modalidades variam muito de uma cultura para outra. (METZ, 1980, p. 271).

A analogia é, portanto, uma junção de códigos perceptivos, códigos de juízo de semelhança e códigos de nominações icônicas. Tal concepção de códigos da analogia acarreta a necessária crítica da impressão de realidade. Metz (1980, p. 330) comenta que, desde o final dos anos 1960, entrou em voga uma série de discussões que mostram que a impressão de realidade é "em si mesma uma ideologia". É tudo uma questão de compreender que a analogia é coisa codificada e a realidade é muito mais próxima de uma construção ou codificação do que de uma impressão.

O que se chama de realidade - isto é, os diversos elementos profílmicos nada mais é que um conjunto de códigos: o conjunto dos códigos sem os quais esta realidade não seria acessível ou inteligível, de modo que não se poderia dizer nada a respeito dela, e nem mesmo que ela é a realidade. Se o filme é "invenção" ou "criação", é unicamente na medida em que é operação, na medida em que acrescenta algo aos códigos preexistentes, na medida em que traz consigo configurações estruturais que nenhum deles previa. Por isso, o próprio acréscimo (o coeficiente de modificação e de trabalho que é próprio do texto) não intervém com relação a uma realidade bruta, nem com relação a certo nada que, estranhamente, 
trouxesse consigo a promessa de uma futura e infalível criatividade, mas com relação a códigos. Eis por que o momento do código parece conservar toda a sua importância: não apenas porque o estudo dos códigos, fora de qualquer sistema fílmico, é, para a pesquisa semiológica, um objetivo em si (embora não o único), mas porque os próprios sistemas filmicos, enquanto movimentos ativos de deslocamento, só são inteligiveis se se tem alguma ideia do que foi deslocado. (METZ, 1980, p. 124, grifo nosso).

A realidade é composta por códigos, assim como o cinema. Conforme a materialidade e a singularidade de cada texto, são percebidos diferentes traços códicos. A ideia, portanto, de que o cinema revela algo imediatamente, isto é, sem mediação, ignora tanto a relação necessariamente conflituosa entre os códigos e os textos quanto a codificação mesma da realidade sociocultural que nos permeia. À luz de uma semiologia metziana, somos levados a indagar pelos códigos que Kiarostami desloca ou desvia. Por vezes tem-se o conflito, a partida e o retorno, descrevendo-se uma parábola que não deixa de evocar as axiomáticas da narrativa, ainda que a finalidade (o retorno) se tenha preenchido agora de desvios casuais que a adiam indefinidamente. Em outros momentos, emancipa-se o desvio: assistimos a um deslocamento ocioso, excesso não-narrativo como limite descodificante.

A discussão que Bazin e Metz promovem no espaço da teoria do cinema constitui a pergunta pelo Real. 0 que é realizado no filme? As imagens que se prolongam na tela revelam algo de nossa realidade? Ou a própria operação fílmica consiste em criar, inventar, produzir essa realidade? Parece de suma importância para tais autores saber se o mundo recortado se situa antes ou depois do filme; se o cinema desvela ou constrói. Essa pergunta, que ecoa no cinema moderno em seu contínuo jogo fabulatório de verdades e mentiras, não parece assombrar os arranjos ociosos de Kiarostami. Em Close-up, apenas, a relação realirreal é suscitada - e respondida nos termos de Sabzian: ao dizer-se cineasta, ele tornou-se cineasta, ou seja: não há nada mais real do que a própria representação.

Roland Barthes entende o "efeito de real" menos como consequência da materialidade do espetáculo (como lemos nos primeiros textos de Metz) do que como um certo arranjo simbólico. Ao dissertar sobre a literatura de Flaubert, o autor quebra os laços com os referentes e encontra o "real" em minúcias supérfluas e nada funcionais estabelecidas no texto: 
A singularidade da descrição (ou do "detalhe inútil") no tecido narrativo, sua solidão, aponta para uma questão que tem a maior importância para a análise estrutural dos discursos narrativos. Esta questão é a seguinte: tudo, no discurso narrativo, é significante, e se não for, se subsistem no sintagma narrativo algumas regiões insignificantes, qual é definitivamente, se assim podemos dizer, a significação dessa insignificância? (BARTHES, 1972, pp. 37-38).

Diante desse excesso descritivo identificado nos romances realistas, o semiólogo passa a ler a significação do "detalhe inútil" como uma espécie de performatividade do real, isto é, longe de revelar ou reforçar a verdade ou o peso de um referente, esse tipo de escrita (de mise en scène?) aponta para si própria como real, como coeficiente de realidade (externa) interna ao texto.

Isto é o que se poderia chamar de ilusão referencial. A verdade desta ilusão é a seguinte: suprimido da enunciação realista, a título de significado de denotação, o "real" volta para ela, a título de significado de conotação; pois no mesmo instante em que esses detalhes são supostos denotarem diretamente o real, eles não fazem mais que o significarem, sem dizê-lo: o barômetro de Flaubert, a pequena porta de Michelet, não dizem nada mais que isto: somos o real; é a categoria do "real" (e não seus conteúdos contingentes) que é então significada; ou melhor, a própria carência do significado em proveito do único referente torna-se o próprio significante do realismo: produz-se um efeito de real, fundamento desse inverossímil inconfessado que forma a estética de todas as obras correntes da modernidade. (BARTHES, 1972, p. 43).

Barthes traduz essa invasão do real como uma expulsão do significado, restando uma combinação do referente com o significante. Essa escritura aposta na exposição de pequenos gestos, objetos sem importância aparente, palavras redundantes descompromisso com a significação narrativa, o rastro do real... Intrusas em meio à economia da narrativa, folgam palavras sem finalidade, passando por realidade remanescente, heroicamente vã, contra toda intenção autoral.

É outra a questão que os pequenos detalhes, que esses sintagmas ociosos levantam enquanto problema semiótico. Seja qual for sua relação com o mundo, esses trechos de filme impõem-se à revelia de um sentido global da narrativa. É como se, no interior do sistema 
que costura a significação do filme, houvesse traços que implodem o sistema, um excesso que se autonomiza em suas relações diante de um todo de sentido.

\section{Crítica do efeito de real e liberação dos sintagmas ociosos}

Em crítica a Barthes, o filósofo Jacques Rancière (2010, p. 76) aponta outro caminho para a leitura desses traços que se supõem insignificantes, sugerindo que a descrição, na análise barthesiana, aparece como "um excesso que cobre uma falta", um sem-fim de representações de objetos e assemelhados que fica no caminho do enredo; descrições sem finalidade narrativa. Contudo, o semiólogo se via obrigado a incorporar tais detalhes no interior da estrutura, batizando a descrição como efeito de real e tornando-a subordinada à narrativa - desde agora, narrativa realista.

Interessante remanejamento de Rancière: já não se trata da realidade. A realidade nunca foi o caso. A questão do realismo seria antes a insultuosa descoberta de uma igualdade geral de condições de perceber e de agir. A exigência econômica da análise estrutural se irmanaria à promoção modernista de uma "necessidade interna" inerente ao desenvolvimento da criação artística, ambas as atitudes incorrendo na clássica (e aristocrática) subordinação das partes em relação ao todo. 0 efeito de realidade não passa de um efeito de igualdade que vem implodir a codificação do verossímil: "Verossimilhança não é somente sobre que efeito pode ser esperado de uma causa; ela também diz respeito ao que pode ser esperado de um indivíduo vivendo nesta ou naquela situação, que tipo de percepção, sentimento e comportamento pode ser atribuído a ele ou ela" (RANCIÈRE, 2010, p. 79).

Verossímil seria que cada um permanecesse em seu lugar designado, segundo classificação prévia: a criança e o miserável, enquanto respeitassem posições estruturais (a "necessidade interna" que dita a sua verossimilhança), não permitiriam o cinema de Kiarostami. Porém, diz Rancière (2010, p. 80) em favor da fabulação, é “[...] esta nova capacidade de qualquer um de viver vidas alternativas que coíbe a subordinação das partes ao todo". O realismo literário incomoda desde que, ociosamente, inutilmente, cede sensibilidade a filhos de artesãos e camponeses, contra toda lei de causa e efeito, que 
excluiria esses personagens de qualquer curso de eventos digno de nota. A afronta contida nessa "invasão do real" seria mesmo uma ociosidade que sobrepuja qualquer necessidade, finalidade ou sentido. Em seu ócio pleno, o elemento "insignificante" não precisa de nada além do estar-ali.

Veremos o enquadramento de Kiarostami estender essa equalização do sensível para a ociosidade das coisas, tomando como fortuna de redistribuição já não diretamente a sensação, mas antes o movimento. Redistribuição geral do movimento, liberado de finalidade, despido de qualquer "necessidade interna". Entendemos que o cinema de Kiarostami descreve um percurso que começa estudando a ingenuidade do movimento na ingenuidade dos fins (objetivo obstinadamente fabulado) e culmina em um abandono da finalidade em favor de uma política do ócio. Intimidade, portanto, entre o ingênuo e o ocioso, que, evadindo-se a um sentido previamente estabelecido, surgem como realidade remanescente ou insistente. 0 modo de existência da parte ociosa, apanhado segundo o ponto de vista (o forçoso ponto de chegada) da finalidade, aparece como função fabulatória do personagem ingênuo. Liberado, porém, dessa remissão aos fins, o movimento ocioso aparece enquanto tal, errância pura.

Figuras 1 e 2 - Zigue-zague em Onde fica a casa do meu amigo? e em Através das oliveiras.

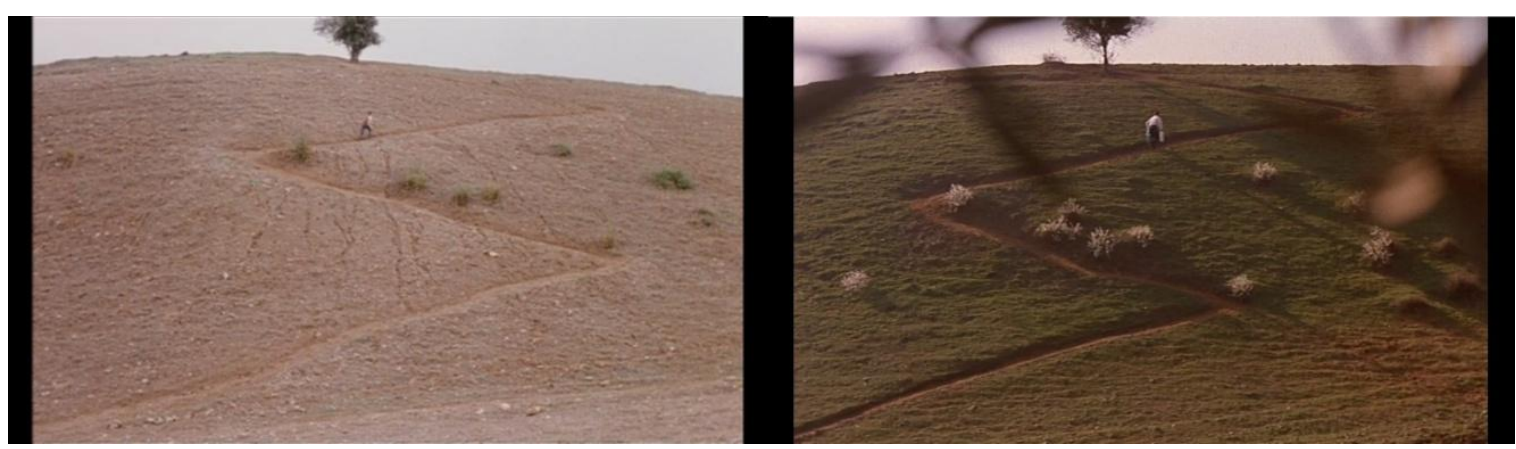

Fonte: Frames de Onde fica a casa do meu amigo? (1987) e Através das oliveiras (1994).

Cumpre agora traduzirmos a discussão estético-política de Rancière, ancorada na relação literária entre parte e todo, nos termos de uma semiologia atenta à materialidade do cinema. Tal como o encontramos em Christian Metz (2006), o conceito de sintagma faz as vezes da parte fílmica: correlação de elementos presentes como unidade mínima de análise. Trata-se, aqui, de destacar sintagmas ora do desvio teimoso, dos quais é exemplar, em 
Kiarostami, o zigue-zague do herói ingênuo (Figuras 1 e 2); ora de uma errância que já não se deixa absorver por qualquer fim.

Sintagma 1 (Figuras 3, 4, 5 e 6) - Espera e movimento ocioso em Close-up (1990)

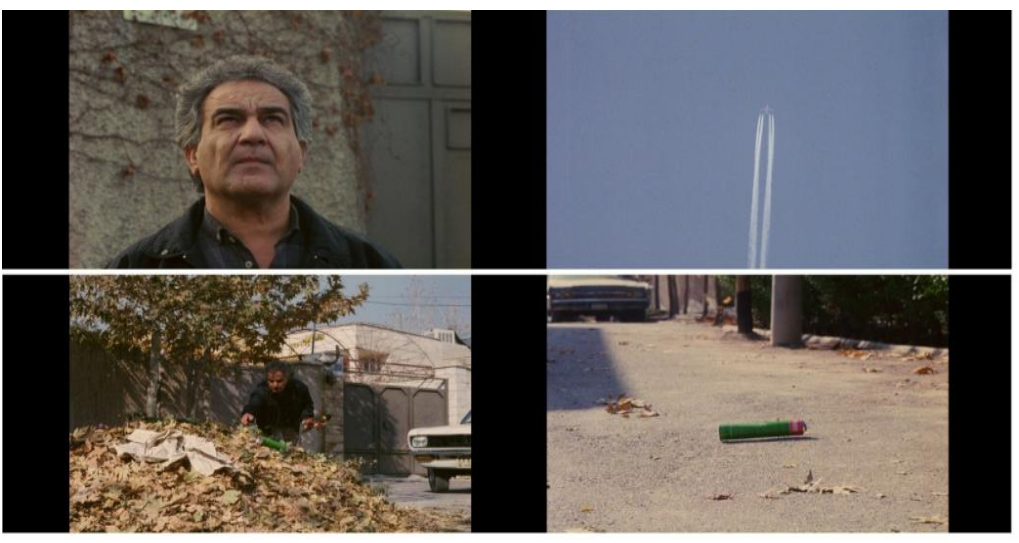

Fonte: Frames de Close-up (1990).

Pelo menos duas sequências reclamam autonomia em Close-up (1990), ambas conectadas de forma tênue à narrativa. No primeiro caso (sintagma 1), é a própria espera que se emancipa do curso dos eventos, dilatando-se sem qualquer consequência narrativa. 0 personagem é o primeiro a deixar-se contemplar, à toa, o voo também sem propósito de um avião, antes de se pôr a catar flores dispersas em um amontoado de folhas secas. A retirada das flores move uma lata, que cai no asfalto para receber um chute displicente e rolar por quase 40 segundos até estancar na sarjeta. Retoma-se a narrativa, mas logo depois retornamos à lata, que desce mais um tanto de ladeira, entre o chute do repórter e a impressão do jornal (sintagma 2). 0 jornal indica a continuidade da narrativa para seu sentido final; a lata que rola não será mais retomada.

Sintagma 2 (Figuras 7, 8, 9 e 10) - Retorno do ocioso em Close-up (1990) 


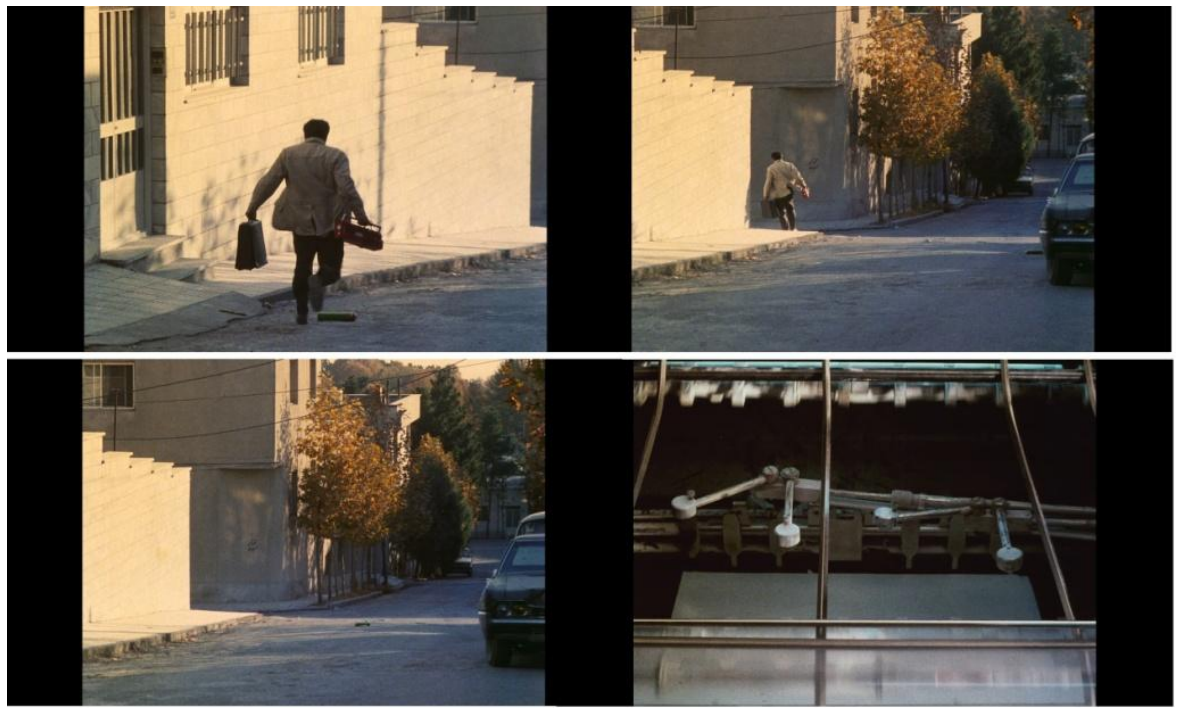

Fonte: Frames de Close-up (1990).

Já no filme Cinco (2003), observamos a implosão da relação entre as partes e o todo. A ideia de causalidade não mais habita os espaços, não os encadeia em adequação a um fim. O filme inicia-se, após os créditos iniciais, com um plano de aproximadamente oito minutos de um tronco que rola (Figura 11). 0 desinteressante (desinteressado?) pedaço de madeira inicia sua inerte jornada estacionado na areia da praia até que a teimosa frequência das ondas acaba por tomá-lo. 0 vaivém do mar produz um circuito de atração-repulsão do tronco, que rola rumo às profundezas até ser arrastado de volta para a orla e assim continuamente até o minuto quinto de projeção, quando o tronco então deixa para trás uma parte de si. Esta, insubordinadamente, prefere não ser tragada pelo mar, residindo em terra firme. 0 plano, até então se movimentando horizontalmente para seguir o objeto do olhar, encerra-se à parte imóvel, enquanto o resto do tronco se direciona para fora de quadro (Figura 12), retornando à visão uma última vez antes de abandonar finalmente o plano, que se encerra logo após seu sumiço (Figura 13). No próximo plano (Figura 14) e nos posteriores, o tronco não será retomado.

Sintagma 3 (Figuras 11, 12, 13 e 14): A jornada do tronco e a ausência de causalidade entre os planos 

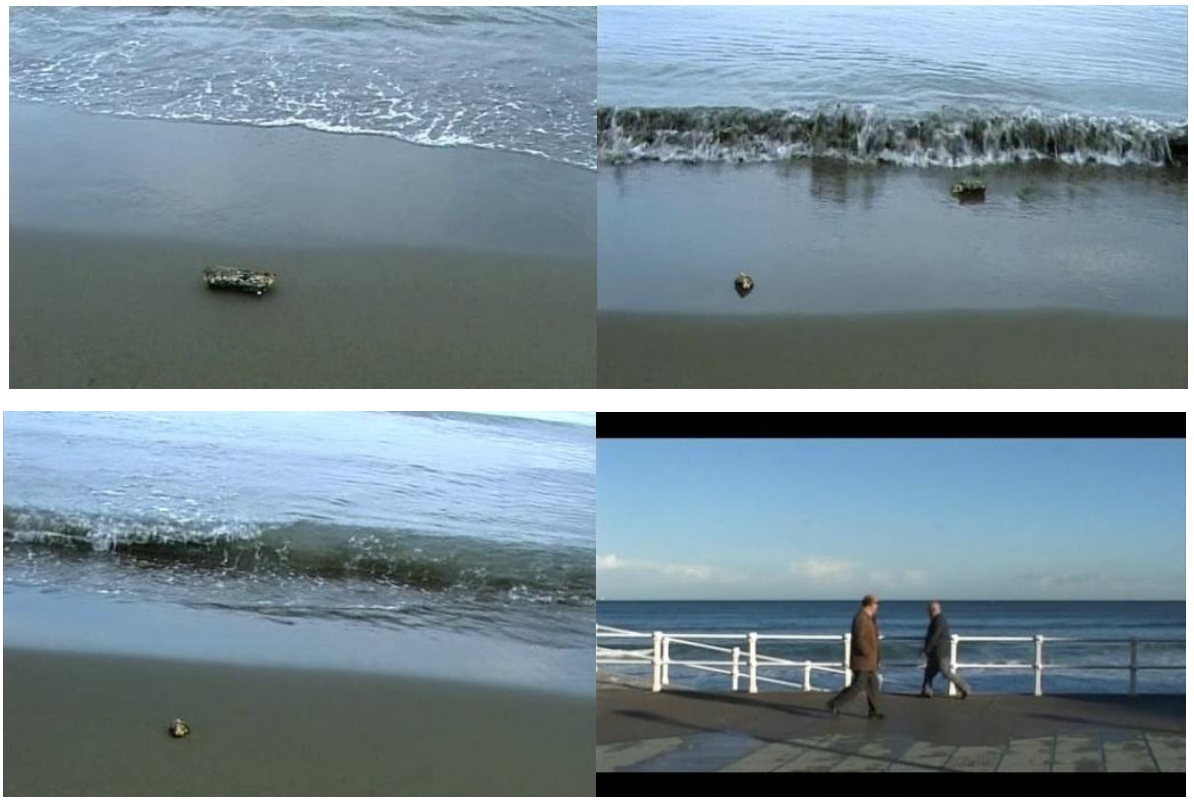

Fonte: Frames do filme Cinco (2003).

O movimento mapeado neste terceiro sintagma nos leva a discutir o ócio não mais como um traço códico que confronta o todo significativo da estrutura, mas como o próprio limite do código. Sintagma que se autonomiza; emancipado da determinação causal da narrativa, torna-se errância e liberdade. É toda uma nova política que surge da resiliência superficial dos objetos, um perspectivismo que produz o protagonismo da paisagem e das minúcias vãs, dos pormenores da narrativa transformados em agentes de autodeterminação. Reiteramos o comentário de Bernardet quando abraça os temas da poesia persa: uma eterna fábula do movimento e dos obstáculos que o enformam: a sinuosidade do rio, o rolar da lata, o navegar do tronco, o contínuo, o fluxo vagabundo do ócio, o deslizamento do código, a democracia dos objetos, a vitória da paisagem e das coisas pequenas. É um olhar generoso para um mundo muito grande. É sobre a perspectiva, em última instância, que se impõe a pergunta do cineasta.

\section{Financiamento}

O presente artigo foi realizado com o apoio da Coordenação de Aperfeiçoamento de Pessoal de Nível Superior - Brasil (CAPES) e do Conselho Nacional de Pesquisa (CNPq). 


\section{Agradecimentos}

Deu impulso à escrita deste artigo a Profa ministrou na Faculdade de Educação da UFRGS, no primeiro semestre de 2018, a disciplina Seminário Avançado de Narrativa, Imagem e Processos Criativos: provocações do cinema de Abbas Kiarostami à educação.

\section{Referências}

ATRAVÉS das oliveiras. Direção: Abbas Kiarostami. Irã: Abbas Kiarostami Productions, 1994, $35 \mathrm{~mm}$ (103 min.).

BARTHES, Roland. 0 efeito de real. In: BARTHES, R. et al. Literatura e Semiologia.

Petrópolis: Editora Vozes, 1972. p. 35-44.

BAZIN, André. 0 cinema: ensaios. São Paulo: Brasiliense, 1991.

BERNARDET, Jean-Claude. Caminhos de Kiarostami. São Paulo: Cia das Letras, 2004.

CINCO. Direção: Abbas Kiarostami. Irã: Behnegar; França: MK2; Japão: NHK, 2003. 1 DV (74 min.).

CLOSE-UP. Direção: Abbas Kiarostami. Irã: Kanoon, 1990. 35 mm (90 min.).

ISHAGHPOUR, Youssef. O real, cara e coroa. In: KIAROSTAMI, A. Abbas Kiarostami. São Paulo: Cosac Naify, 2004.

KIAROSTAMI, Abbas. Duas ou três coisas que sei de mim. In: KIAROSTAMI, A. Abbas Kiarostami. São Paulo: Cosac Naify, 2004.

MELVILLE, Herman. Bartleby, o escrevente: uma história de Wall Street. São Paulo: Grua, 2014.

METZ, Christian. A significação no cinema. São Paulo: Perspectiva, 2006.

METZ, Christian. Linguagem e cinema. São Paulo: Perspectiva, 1980.

ONDE fica a casa do meu amigo? Direção: Abbas Kiarostami. Irã: Kanoon, 1987. 1 DVD (87 $\min )$. 
RANCIÈRE, Jacques. 0 efeito de realidade e a política da ficção. Novos Estudos CEBRAP, São Paulo, v. 29, n. 1, ed. 86, p. 75-90, mar. 2010.

\title{
From reality effect to a politics of idleness in Abbas Kiarostami
}

\begin{abstract}
Abbas Kiarostami's movies and theoretical writings manifest a technique of observing little details in continuous motion to evoke a sense of reality. This article investigates how the director conceives idleness as a device for instilling in the viewer such reality effect. This study of vain movements changes once it is subordinate to narrative causality, resulting in a semiotic of naiveté. With the support of the studies by André Bazin, Christian Metz, Roland Barthes and Jacques Rancière, we trace a path which presents human and non-human characters as stubborn vectors of a politics of idleness.
\end{abstract}

\section{Keywords}

Abbas Kiarostami. Reality effect. Naiveté. Idleness. Film semiotics.

Recebido em 15/05/2019

Aceito em 01/07/2019 